\title{
The Relationship of Vaccination Status with Implementation Worship Behavior during the COVID-19 Pandemic in Indonesia
}

\author{
Budi Santoso'), Siti Mar'atul Munawaroh²), Asri Lestari3) \\ 1)Faculty of Health Sciences, Universitas 'Aisyiyah Yogyakarta \\ 2)Masters' Program in Public Health, Universitas Sebelas Maret \\ 3)Faculty of Public Health, Universitas Ahmad Dahlan
}

\section{ABSTRACT}

Background: COVID-19 pandemic has certainly brought tremendous global impacts in various sectors of life, such as social activities that are becoming increasingly limited. In addition, another impact is the prohibition of the implementation of collective worship of Muslims in Indonesia. The government implements health protocols as the main capital to stop the expansion of the pandemic. In addition, the use of vaccines with great hope as one of the main weapons to control COVID-19. This study aims to analyze the relationship between vaccination status and behavior in the implementation of Ramadan worship during the COVID-19 pandemic in Indonesia.

Subjects and Method: A cross-sectional study was conducted in Indonesia from April to May 2021, with the research subjects being members of the Muhammadiyah Disaster Management Center (MDMC). A sample of 746 study subjects was selected for this study. The dependent was worship behavior. The independent variable was vaccination status. The data were analyzed by Chi-square test.

Results: Complete vaccination status improved the worship behavior during the COVID-19 pandemic $(\mathrm{OR}=1.92 ; 95 \% \mathrm{CI}=1.43$ to 2.57 ; $<$ 0.001).

Conclusion: Complete vaccination status improves the worship behavior during the COVID-19 pandemic.

Keywords: vaccination status, worship behavior, COVID-19

\section{Correspondence:}

Budi santoso. Faculty of Health Sciences, Universitas 'Aisyiyah Yogyakarta, Jl Ring Road Barat 63 Mlangi Nogotirto Gamping Sleman 55292. Email: sitimaratulo8@gmail.com. Phone: +6281919120118 .

Cite this as:

Santoso B, Munawaroh SM, Lestari A (2021). The Relationship of Vaccination Status with Implementation Worship Behavior during the COVID-19 Pandemic in Indonesia. J Health Promote Behav. 06(02): 91-96. https://doi.org/10.26911/thejhpb.2021.06.02.01.

cc) (†) (-) Journal of Health Promotion and Behavioris licensed under a Creative Commons Attribution-NonCommercial-ShareAlike 4.0 International License.

\section{BACKGROUND}

COVID-19 is an infectious disease caused by a novel coronavirus (SARS-Cov-2) at the end of December 2019 (Huang et al., 2020; Chen et al., 2020). The situation of COVID19 in the world is still increasing. Update on COVID-19 cases as of July 16, 2021, there are $188,655,968$ confirmed cases of COVID19 worldwide, including 4,067,517 deaths and the addition of cases per day is around 3000-400o people (WHO, 2020a).
Today the world applies health protocols as the main capital to stop the expansion of the pandemic. In addition, the use of vaccines has begun with great hope as one of the main weapons in controlling COVID19 (Aditama, 2020). Meanwhile, the number of people who have been injected with the first dose of the Covid-19 vaccine is $66,353,669$ people (31.86\%) (Ministry of Health, 2021). 
Human-to-human transmission is the main source of the spread of COVID-19. This can happen because COVID-19 can be transmitted through droplets when someone coughs or sneezes. Human-to-human transmission of the disease makes it easy for the disease to spread quickly (Susilo et al., 2019; WHO, 202Ob).

The COVID-19 pandemic has of course brought tremendous global impacts in various sectors of life, such as increasingly limited social activities. In addition, another impact is the prohibition of the implementation of collective worship of Muslims in Indonesia (Imaduddin, 2020).

Various policies from the government during the month of Ramadan were carried out to overcome the COVID-19 pandemic. Social distancing (social restrictions) and lockdowns are carried out by various countries to break the chain of transmission of COVID-19 (Valerisha et al., 2020). The community is also required to carry out work from home (work from home) and also carry out worship from home during the COVID-19 pandemic, which means that people are more active at home than outside (Mustajab et al., 2020). These behaviors are one way that can be done to prevent the transmission of COVID-19 (Prihantama, 2020).

Changes in health behavior have the aim of improving the quality of a person's health so that they can meet health standards by means of social distancing, working from home, using masks, or other activities such as worshiping from home. The following steps are taken as a form of preventing the spread of COVID-19. This study aims to analyze the relationship between vaccination status and changes in health behavior during Ramadan during the COVID-19 pandemic in Indonesia.
SUBJECTS AND METHOD

\section{Study Design}

A cross-sectional study was conducted in Indonesia, from April to May 2021.

\section{Population and Sample}

The study population is members of the Muhammadiyah Disaster Management Center (MDMC) in Indonesia. The number of study subjects was 746 .

\section{Study Variables}

The dependent variable was worship behavior. The independent variable was vaccination status.

\section{Operational Definition of Variables}

Behavior is a person's action in responding to a stimulus from the environment which is indicated by interactions such as making decisions about health behavior (decisionmaking) and health preparation for further action (preparation for action). The measurement scale is categorical. Categories are divided into 1) negative and 2) positive.

Vaccination status is a condition when the subject has done the complete vaccination or the second dose. Vaccination status was categorized into 1) complete vaccine or 2 vaccines, and 2) unvaccinated or one-time vaccine. The measurement scale is categorical.

\section{Instruments}

The study instrument used was a validated questionnaire. Data collection is done using google form.

\section{Data Analysis}

Data were analyzed using bivariate test with confidence interval (CI 95\%) with the provision of significance $\mathrm{p}<0.05$. by using the help of the Statistical Package for the Social Science (SPSS) version 25.0 for windows.

\section{RESULTS}

\section{Sample Characteristics}

Most of the study subjects aged 26-25 years were 330 people $(44.2 \%)$, the majority of 
Santoso et al./ Vaccination Status and Worship Behavior during the COVID-19 Pandemic

subjects had a D4/S1 education level as many as 336 people (45.0\%), with the majority of subjects having received a complete vaccine as many as 395 people (52.9\%), with employment as private employees as many as 338 people.

Table 1. Characteristics of the sample

\begin{tabular}{lcc}
\hline Variable & Frequency & Percentage \\
\hline Age & 193 & \\
Teenager (12-25 years) & 330 & $25.9 \%$ \\
Adult (26-45 years) & 223 & $44.2 \%$ \\
Elderly (46-65 years) & & $29.9 \%$ \\
Education & 1 & \\
PS & 3 & $0.1 \%$ \\
JHS & 86 & $0.4 \%$ \\
SHS & 336 & $11.5 \%$ \\
D4/S1 & 320 & $45.0 \%$ \\
S2/S3 & & $43.0 \%$ \\
Vaccination Status & 351 & \\
Incomplete & 395 & $47.1 \%$ \\
Complete & & $52.9 \%$ \\
Occupation & 338 & \\
Private Employee & 166 & $45.3 \%$ \\
Civil Servant & 96 & $22.3 \%$ \\
Teacher & 46 & $12.9 \%$ \\
Retired civil servant & 29 & $6.2 \%$ \\
Lecturer & 27 & $3.88 \%$ \\
Housewife & 18 & $3.62 \%$ \\
Student & 11 & $2.4 \%$ \\
Nurse & 6 & $1.47 \%$ \\
Doctor & 2 & $0.8 \%$ \\
Labor & 2 & $0.3 \%$ \\
Unemployment & 1 & $0.3 \%$ \\
Members of the & House & $0.3 \%$ \\
Representatives & 1 & $0.1 \%$ \\
Pharmacist & 1 & $0.1 \%$ \\
ASN (State Civil Apparatus) & & $0.1 \%$ \\
Midwife & & $0.1 \%$ \\
Consultant & &
\end{tabular}

\section{Bivariate Analysis}

Based on Table 2, it can be seen that vaccination status was completely related to the health behavior of Ramadan activities during the pandemic and was statistically significant $(\mathrm{OR}=1.92 ; 95 \% \mathrm{CI}=1.43$ to 2.57 ; $\mathrm{p}<0.001)$.

Table 2. The Relationship between Vaccination Coverage and Behavior of the Implementation of Ramadan Worship During the COVID-19 Pandemic

\begin{tabular}{|c|c|c|c|c|c|c|c|c|}
\hline \multirow{3}{*}{ Variable } & \multicolumn{4}{|c|}{ Worship behavior } & \multirow{3}{*}{ OR } & \multicolumn{2}{|c|}{$95 \%$ CI } & \multirow{3}{*}{$\mathbf{p}$} \\
\hline & \multicolumn{2}{|c|}{ Negative } & \multicolumn{2}{|c|}{ Positive } & & \multirow{2}{*}{$\begin{array}{c}\text { Lower } \\
\text { limit }\end{array}$} & \multirow{2}{*}{$\begin{array}{l}\text { Upper } \\
\text { limit }\end{array}$} & \\
\hline & $\mathbf{n}$ & $\%$ & $\mathbf{n}$ & $\%$ & & & & \\
\hline Vaccination Status & & & & & & & & \\
\hline Incomplete & 213 & 61 & 138 & 39 & 1.92 & 1.43 & 2.57 & $<0.001$ \\
\hline Complete & 176 & 45 & 219 & 55 & & & & \\
\hline
\end{tabular}


Santoso et al./ Vaccination Status and Worship Behavior during the COVID-19 Pandemic

\section{DISCUSSION}

To deal with the COVID-19 pandemic, the government has made various policies to protect the community from the transmission and impact of COVID-19, starting from large-scale social restrictions including restrictions on schools, workplaces, places of worship, public places and transportation, providing social assistance, providing incentives for workers. health, mask policies for all and policies for implementing health protocols in various places that continue to be echoed while waiting for a vaccine (Iskak et al., 2021).

Vaccines are one way that is considered capable of accelerating the normalization of conditions so that we are able to live life back to normal. Even so, that does not mean there are no other solutions. Vaccination is one of the other efforts that can be carried out, namely by providing immunity to diseases, including COVID-19. With more and more people becoming immune to the virus, it is hoped that in the future there will be herd immunity, or group immunity where everyone already has immunity and no longer transmits the virus to others.

The subjects of this study are members of the Muhammadiyah Disaster Management Center (MDMC) who are domiciled in Indonesia. Most of the subjects in this study had complete vaccinations. Behaviors that can reduce transmission of COVID-19 with vaccine status include physical distancing (Drury et al., 2021). This is in line with related results which show that some respondents who have been completely vaccinated have positive behavior, in this case the subject follows social restrictions to minimize the transmission of COVID-19.

This study shows that vaccination status is associated with behavioral changes in the implementation of worship in the month of Ramadan. Almost all people follow social distancing and pay attention to other steps that have been determined to avoid infection/spread of COVID-19. This study is in line with research conducted in India (Singh, 2020).

Most of the study subjects had an undergraduate education level. This is in accordance with the results because subjects with a high level of education are possible to have positive behavior, meaning that the subject adheres to social distancing. The results of this study are in line with Gannika and Sembiring, 2020; Pertiwi \& Budiono, 2021, which shows that some respondents who always carry out Covid-19 prevention behaviors are respondents who are highly educated.

This study is not in line with the Meliza et al. (2020) which states that the perception of the people in Sukaraja in responding to restrictions on the implementation of worship during the COVID-19 pandemic is diverse. This difference is motivated by different understandings about Covid-19 and about the background of circulars relating to worship at home and different views on the boundaries of worship in the green and red zones. The existence of these various perceptions can cause people not to carry out social restrictions such as social distancing or at home, especially in worshiping during the month of Ramadan. Most people think that mosques must be used properly even though they are in a pandemic. In addition, community culture is also associated with non-compliance with social restriction regulations, such as the existence of a culture of breaking together outside the home which can increase the risk of COVID-19 transmission.

Febriyanti et al. (2021) stated that out of a total of 37 subjects who knew about the vaccination program, $83.8 \%$ and about $81 \%$ 
Santoso et al./ Vaccination Status and Worship Behavior during the COVID-19 Pandemic

agreed to be vaccinated. Research subjects who do not agree to be vaccinated for fear of side effects. With the existence of diverse public perceptions, it can cause people not to follow social restrictions, it is hoped that the government will be more passive in disseminating health by involving all parties, either directly or with the media.

\section{AUTHOR CONTRIBUTION}

Budi Santoso collects and formulates data, and designs research. Siti Mar'atul Munawaroh and Asri Lestari examine the data and analyze the data.

\section{FUNDING AND SPONSORSHIP}

This study is self-funded.

\section{CONFLICT OF INTEREST}

There is no conflict of interest in this study.

\section{ACKNOWLEDGMENT}

The author would like to thank the MDMC members who have contributed and are willing to be research subjects in this study.

\section{REFERENCES}

Aditama TY (2020). COVID-19. Jakarta: Badan Penelitian dan Pengembangan Kesehatan (LPB).

Chen N, Zhou M, Dong X, Qu J, Gong F, Han Y, Qiu Y, et al. (2020). Epidemiological and clinical characteristics of 99 cases of 2019 novel coronavirus pneumonia in Wuhan, China: a descriptive study. Lancet. 395(10223): 507-513. DOI: 10.1016/So140-6736(20)30211-7.

Drury J, Mao G, John A, Kamal A, Rubin GJ, Stott C, Vandrevala T, Marteau TM (2021). Behavioural responses to Covid-19 healthcertification: a rapid review. BMC Public Health. 21:1205. DOI: https://doi.org/10.1186/s12889o21-11166-o
Febriyanti N, Choliq MI, Mukti AW (2021). hubungan tingkat pengetahuan dan kesediaan vaksinasi covid-19 pada warga Kelurahan Dukuh Menanggal Kota Surabaya (The relationship between the level of knowledge and willingness to vaccinate COVID-19 among residents of Dukuh Menanggal Village, Surabaya City). Program Studi Farmasi, Fakultas Sains dan Kesehatan, Universitas PGRI Adi Buana Surabaya.

Gannika L, Sembiring E (2020). Tingkat Pengetahuan dan Perilaku Pencegahan Coronavirus Disease 2019 (COVID-19) Pada Masyarakat Sulawesi Utara (Level of Knowledge and Behavior of Prevention of Coronavirus Disease 2019 (COVID-19) in North Sulawesi Community). Jurnal Keperawatan, 16(2), 83-89

Huang C, Wang Y, Li W, Ren L, Zhao J, Hu Y, Zang L, et al. (2020). Clinical features of patients infected with 2019 novel coronavirus in Wuhan, China. Lancet. 395(10223): 497-506. DOI: 10.1016/So140-6736(20)30183-5

Imaduddin MF (2020). Studi persepsi masyarakat terhadap fatwa mui no. 14 tahun 2020 tentang penyelenggaraan ibadah dalam situasi wabah COVID19 (The study of public perception of the fatwa mui no. 14 of 2020 regarding the implementation of worship in the COVID-19 outbreak situation). JISA: Jurnal Ilmiah Sosiologi Agama. 3(2): 92-113.

Iskak, Rusydi MZ, Hurauruj R, Chakim S, Ahmad WR (2021). Meningkatkan kesadaran masyarakat tentang pentingnya vaksinasi di Masjid Al-Ikhlas, Jakarta Barat (Raising public awareness about the importance of vaccination at Al-Ikhlas Mosque, West Jakarta). Jurnal PADMA: Pengabdian 
Santoso et al./ Vaccination Status and Worship Behavior during the COVID-19 Pandemic

Dharma Masyarakat. 1(3): 222-226.

Mustajab D, Bauw A, Rasyid A, Irawan A, Akbar MA, Hamid MA (2020). Fenomena bekerja dari rumah sebagai upaya mencegah serangan COVID-19 dan dampaknya terhadap produktifitas kerja (The phenomenon of working from home as an effort to prevent the COVID-19 attack and its impact on work productivity). The International Journal of Applied Business. 4(1): 13-2s1.

Pertiwi GS, Budiono I (2021). Perilaku physical distancing masyarakat pada masa pandemi covid-19 (Community physical distancing behavior during the covid-19 pandemic). IJPHN 1 (1) (2021) 90-100. DOI: http://journal.unnes.ac.id/sju/index.php/IJPHN

Prihantama (2020) Perilaku hidup bersih dan sehat cegah COVID-19. Sleman: Dinas Kesehatan Sleman (Clean and healthy living behavior to prevent COVID-19. Sleman: Sleman Health Office; 2020). Accessed from https://dinkes.slemankab.go.id/peril aku-hidupbersih-dan-sehat-cegahcovid-19.html.

Singh B (2020). Study of Human Behaviour During Lockdown Owing to Corona Epidemic. Lecture Notes in Electrical
Engineering 766, pp. 729-739. DOI: 10.1007/978-981-16-1476-7_65

Susilo A, Rumende CM, Pitoyo CW, Santoso WD, Yulianti M, Herikurniawan $\mathrm{H}$, et al. (2020). Coronavirus disease 2019: Tinjauan literatur terkini. J Penyakit Dalam Indones. 7(1): 45-67 6. http://dx.doi.org/10.7454/jpdi.v7i1 .415 .

Valerisha A, Putra MA (2020). Pandemi global COVID-19 dan problematika negara-bangsa: Transparansi data sebagai vaksin socio-digital? Jurnal Ilmiah Hubungan Internasional (The global COVID-19 pandemic and nation-state problems: Data transparency as a socio-digital vaccine? Scientific Journal of International Relations). DOI: https://doi.org/10.26593/jihi.voio.3871.131-137.

WHO (2021a). WHO Coronavirus (COVID19) Dashboard. World Health Organization. Retrieved from: https://covid19.who.int/.

WHO (2021b). Clinical management: Living guidance COVID-19. World Health Organization. Retrieved from: https://www.who.int/publications/i/i tem/-WHO-2019-nCoV-clinical-20211. 